\title{
Bilgi Yönetimi ile Yenilik Arasındaki Illişkide Örgüt İçi Dinamiklerin Ara Değişkenlik Etkisini Belirlemeye Yönelik Bir Araştırma
}

\author{
A Research Aimed at Determining The Mediating Effect of Intra-Organizational \\ Dynamics in The Relationship Between Information Management and Innovation
}

\author{
Rana ÖZEN KUTANIS' ${ }^{1}$, Muammer MESCi²
}

\section{ÖZET}

Bu çalışmanın temel amacı, bilgi yönetimi ile yenilik arasındaki ilişkide örgüt içi dinamiklerin ara değişkenlik etkisini belirlemektir. Bu amaç çerçevesinde Türkiye'de faaliyet gösteren beş yıldızlı otel işletmeleri araştırmaya dahil edilmiştir. Araştırmanın yöntemi nicel araştırma yöntemine dayanmaktadır. Araştırmanın verileri anket tekniğinden yararlanılarak toplanmış ve bahsi geçen otel işletmelerinden birer üst düzey "yönetici" aracılığı elde edilmiştir. Toplamda 321 otel işletmesinden veriler elde edilmiş ve bu veriler yapısal eşitlik modellemesi yardımı (Lisrel) ile analize tabi tutulmuştur. Araştırma sonucunda, bilgi yönetimi ile yenilik arasında "örgüt içi dinamiklerin" kısmi aracılık etkisine sahip olduğu belirlenmiştir.

Anahtar Kelimler: Bilgi yönetimi, örgüt içi dinamikler, yenilik, otel işletmeleri

\section{GíRiş}

Günümüzde işletmelerin bilgiyi, "değer" üretme ve amaçlara ulaşmak için bir araç olarak kullandıkları görülmektedir. Bilgi, teknolojinin gelişmesinde yenilik sürecinin önemli bir göstergesidir (Brown ve Patrickson, 2003:499; Özdemir vd., 2007:280).Bilgi tek başına kullanıldığı zaman bir anlam ifade etmemektedir. Bu nedenle bilginin değer kazanmasında rolü bulunan bilgi yönetimine önem verilmelidir. Bilgi yönetimi, örgütsel amaçlara ulaşmak için, tüm çalışanların bilgi ve becerilerinden yararlanmaya olanak sağlayan bir süreçtir (Gümüştekin, 2004:205). Öte yandan, bilgi yönetimi, örgüt içerisinde öğrenme kültürünü oluşturarak sistemli bir biçimde bilgiyi toplayan ve bu bilgiyi örgüt içerisinde paylaştıran bir yaklaşımı ifade etmektedir (Robbins ve Coulter, 2002).

\begin{abstract}
The main purpose of this study is to determine whether " intra-organizational dynamics" has mediatin geffect in there lationshipbetweenknowledgemanagementandinnovation. In the framework of this purpose, the five-star hotel enterprisesfunctioning in Turkey are included in this research. The method of there search is based on quantitative research method. In there search, the data is gatheredutilizing the surveytechnique in the extent of quantitativere searchmethod. Research data is gathered from upper level managers of hotel business enterprises mentione dearlier. The data is gathered from 321 hotel business enterprises in total. Research data is subjectedtoanalysiswith theaid of Structural Equations Modeling (Lisrel). In the conclusions of the research, it is determined that "intra-organizational dynamics " has mediating effect in therelationship between knowledge managementan dinnovation.
\end{abstract}

Keywords: Knowledge management, intra-organization aldynamics, innovation, hotel enterprises.

Bilgi yönetimi, bilgiyi ortaya koyma, bilgiyi örgüt içerisine yayma ve son olarak bilgiyi paylaşma sürecini oluşturmaya zemin hazırlamaktadır. Etkin bir bilgi yönetimi için iyi bir iletişim ve yenilik sürecine ihtiyaç vardır. Günümüz rekabet çevresinde yenilik, işletmelerin sürdürebilir rekabet avantajı sağlamasında önemli bir katkı sağlamaktadır. İşletmelerin etkin bir performans ve yenilik çıktılarına ulaşabilmeleri için yeni pazarlara, yeni üretim faktörlerine ve yenilik yapabilme yeteneklerinin geliştirmeye ihtiyaçları vardır. İşletmelerin yenilik yeteneklerini geliştirebilmeleri için değer üretme sürecinde işletme çalışanlarının bilgi ve beceriyi birlikte ortaya koymaları önemlidir (Huang ve Li, 2009:286). Öte yandan, işletmelerin varlıklarını devam ettirebilmeleri için farklı ürünler, hizmetler, süreçler, pazarlama teknikleri, iş modelleri ve tedarik yöntemlerini geliştirebilmeleri gerekmek-

\footnotetext{
1 Prof. Dr.,Sakarya Üniversitesi, İşletme Fakültesi, İşletme Bölümü, rkutanis@sakarya.edu.tr

${ }^{2}$ Yrd. Doç. Dr., Düzce Üniversitesi, Akçakoca Turizm İşletmeciliği ve Otelcilik Yüksekokulu, Turizm İşletmeciliği Bölümü, muammermesci@duzce.edu.tr
} 
tedir. Bu bağlamda, işletmelerin varlıklarını etkin bir biçimde sürdürebilmeleri için sürekli olarak ürünlerini, hizmetlerini, üretim yöntemlerini değiştirmeleri ve yenilemeleri gerekmektedir. Bu sürecin etkinliği ve verimliliği işletmelerin yapacağı yenilikle ölçülebilir (Tutar vd., 2007:197).

Sürekli bir değişimin ve belirsizliğin yaşandığı günümüzde işletmelerin uzun dönemde varlıklarını sürdürebilmeleri ve rekabet avantajı sağlayabilmeleri için örgüt içi dinamikleri etkin bir biçimde kullanabilmeleri gerekir. Çevresel belirsizliğin ve sürekli değişimin yaşandığı ortamlarda işletmelerin faaliyetlerini etkinlikle sürdürebilmeleri gün geçtikçe güçleşmektedir. İşletmelerin bu olumsuz koşulların üstesinden gelebilmeleri için kaynaklarını doğru ve etkin bir biçimde yönetmelerine ihtiyaç vardır. Örgüt içi dinamikler; liderlik, örgüt kültürü, güç ve politika, örgütsel öğrenme, işletme yapısının işleyişi vb. şeklinde sıralanabilir. Örgütler, örgüt içi dinamikleri, faaliyet gösterdikleri pazarda hem örgütün içsel gücünü arttırmak, hem de rakiplerine karşı güç kazanmak amacıyla kullanmalıdırlar.

Bilgi ile yenilik yönetimi; bilgi ile örgüt içi dinamikler; yenilik ile örgüt içi dinamikler arasındaki ilişkiye yönelik literatürde yapılmış olan bazı çalışmalar mevcuttur. Bu çalışmaların ortak özelliği ise her iki kavram üzerindeki ilişki ölçülmek istenmesidir. Örneğin bilgi ile yenilik yönetimi arasında ne yönde bir ilişkinin olduğu ya da yeniliğin örgüt içi dinamikler üzerindeki etkisi araştırıldığı görülmektedir (Jimenez ve Valle 2010:3; Xu vd.,2010; Frenz ve Gillies, 2009:1127). Bu çalışmayı diğer çalışmalardan farklı kılan yönü, bilgi yönetimi ile yenilik arasında örgüt içi dinamiklerin ara değişkenlik etkisine sahip olup olmadığını tespit etmeye yönelik olarak yapılmış olmasıdır. Diğer önemli bir farklılık ise araştırmanın hizmet sektöründe faaliyet gösteren otel işletmeleri üzerinde yapılmış olmasıdır. Bu çalışmanın sonuçlarının literatüre önemli katkılar sağlayacağı ve literatürde var olan benzer çalışmalarla karşılaştırma yapabilme imkânı sağlayacağı düşünülmektedir.

\section{LITERATÜR INNCELEMESI}

Son yıllarda önemini arttıran konulardan birisi de işletmelerin sahip olduğu soyut değerlerdir. Bu değerler işletmelere etkinlik ve verimlilik konularında önemli avantajlar sağlamaktadır (Kurt, 2004:5). Bu değerlerden biri de "bilgi" dir. Rekabetin sürekli olarak arttığı günümüzde işletmelerin başarısı, bilginin rakiplerden daha hızlı olarak elde edilmesi, işlenmesi ve paylaşılmasına bağlıdır (Yıldırmaz, 2006:2). Ayrıca, işletmelerin başarısı için, bilginin etkin biçimde elde edilmesi ve yönetilmesine ihtiyaç vardır (Boumarafi, 2009:20). İşletmenin, bilgiyi yönetmedeki temel amacı, örtük bilgiyi ortaya çıkaracak yöntemleri bularak açık ve erişilebilir hale getirip, işletmeye fayda sağlayacak şekilde bir araya getirmesidir (Onat, 2010:13). Iş̧letmelerin, bilgiyi ortaya koyma, paylaşma ve işletmenin başarısı için kullanabilmede bilgi yönetimine ve sürecine ihtiyaç duyulmaktadır. Bu süreci etkin bir biçimde yürüten işletmeler verimliliğe ulaşmakta ve kârlılıklarını arttırabilmektedirler (İnce, 2002). Bilgiyi elde ederek, örgüt içerisinde içselleştirme ve paylaşımın gerçekleştirilmesi, yenilik sürecinin temelini oluşturmaktadır.

Yenilik sürecinde bilginin paylaşılması çok önem taşımaktadır. Çünkü işletme içerisinde yapılan etkin bir bilgi paylaşımı, işletmenin performansına pozitif yönde katkı sağlayabilmektedir. Çünkü bilgi, işletmenin rekabet edebilme yetkinliğine ve performansının gelişimine katkı sağlayabilir (Du vd., 2007:40). Yenilik sadece yaratıcılık değildir, bunun yanında uygulamayı da içermektedir. Yeniliğin oluşabilmesi için sınırlı sayıdaki teknik ve bilimsel bilgi yeterli olmayabilir (Man, 2001:229). Şüphesiz, ana kaynak bilgidir. Bu bağlamda işletmeler rekabet avantajı sağlamak için bu değerli kaynağı kullanmaları büyük önem taşımaktadır (Herrmann vd., 2006:22).

Bilgi yönetimi stratejileri, yenilik girişiminin başarılı olmasında kritik bir faktör olarak ortaya çıkmaktadır (Mangiarotti, 2010:655). Bilginin, işletmelerin sürdürülebilir rekabet avantajı sağlamada stratejik bir kaynak olarak önem kazanmasıyla birlikte işletme yöneticileri, bilgi yönetimi stratejilerini oluşturmak için büyük bir çabanın ortaya konulması gerektiğini belirtmektedirler (Choi vd., 2008).

Bilgiden yararlanmanın, yeni ürünleri oluşturmada ve faydalı bir kazanca dönüştürmede önemli bir etkisinin olduğu görülmektedir. Uluslararası işletmelerin yenilik ve bilgi ağını uzun bir süreç içerisinde kullandıkları görülmektedir (Zhang vd., 2009:43).

Otel işletmelerinde bilgi yönetimi ve yenilik konusunda yapılmış bazı çalışmalarda iki kavramın birbiri ile ilişkisi ve çıktıları üzerinde durulmuştur.Bağlieri ve Consoli, (2009:354) yapmış oldukları çalışmalarında, müşteri ilişkilerinde ürün yeniliğinin turistlerin anlayabileceği bir şekilde gerçek iletişim rolü üzerine odaklanılması gerektiğini belirtmişlerdir. Ayrıca, işletme yönetiminin işbirlikçi anlayışa sahip olması gerektiğini ifade etmektedir. Bilginin değeri, yenilik süreci içerisinde müşterilerden elde edilen kazanımlarla sağlanabildiğinden yenilik faaliyetlerinin yerine getirilmesinde müşteriler önemli rol oynamaktadır. Müşterilerin taleplerini değerlendirmeyen işletmelerin başarılı olabilmesi oldukça zordur. 
Huang ve Li (2009:290) yenilik performansı ve sosyal bütünleşme arasındaki ilişkinin bilgi yönetimi üzerindeki rolünü incelemişlerdir. Çalışma sonucunda, yenilik performansı ve sosyal bütünleşme arasındaki ilişkinin bilgi yönetimi üzerinde önemli katkılarının bulunduğu tespit edilmiştir. Bilgi yönetiminin hem sosyal bütünleşme hem de yenilik performansı üzerinde pozitif yönde bir etkisinin bulunduğu görülmektedir.

Plessis (2007:21) de bilgi yönetiminin yenilik üzerindeki rolüne ilişkin bir araştırma yapmıştır. Çalışma sonucunda, örgüt içerisinde bilgi miktarının artışına paralel olarak örgütün yenilik yapma oranında da bir yükselişin bulunduğunu tespit etmiştir. Ayrıca yazar çalışmasında, yeni ürün gelişimi ve yeni teknoloji oluşturmada bilgi yönetiminin çok önemli bir rolünün bulunduğu belirlemiştir.

Öte yandan örgüt içi dinamikler işletmelerin uzun dönemde varlıklarını sürdürebilmeleri ve rekabet avantajı sağlayabilmelerinde önemli bir rol oynamaktadır. Örgüt içi dinamikler, faaliyet gösterilen pazarda hem örgütün içsel gücünü arttırmak, hem de rakiplerine karşı üstünlük sağlamak amacıyla işletmeler tarafından kullanılabilir. Bu dinamikler kısaca açıklandığında; liderlik belirli koşullar altında belirli bireysel ve grup amaçlarını gerçekleştirmek üzere bir kimsenin başkalarının faaliyetlerini etkilemesi, yönlendirmesi ve yönetmesi süreci olarak tanımlanmaktadır (Koçel, 2003:583). Eren, (2003:525) ise liderliği, bir grup insanı belirli amaçlar etrafında toplayabilme ve bu amaçları gerçekleştirmek için onları ne yapacakları konusunda harekete geçirme bilgi ve becerilerinin toplamıdır şeklinde ifade etmektedir. Öte yandan, liderlik yeniliği etkileyen en önemli faktörlerden biridir. Literatürde yapılmış çalışmaların birçoğu dönüşümcü liderliğin yenilik üzerinde pozitif yönlü bir etkisinin olduğunu göstermektedir (Gumusluoğlu ve Ilsev, 2009:270).

Kültür, bir işletme içindeki birey ve grupların davranışlarını yönlendiren normlar, davranış kalıpları, inançlar, tutum ve alışkanlıklar sistemi şeklinde tanımlanabilir (Kutanis, 2010). Uzun, (2007)'a göre örgüt kültürü, örgüt üyelerinin moral, verimlilik, motivasyon ve performansını belirleyen önemli bir etkendir. Ayrıca yazar, bir örgüt, kültürünün temelini oluşturan varsayımları, değerleri ve inançları doğrultusunda harekete geçilebilirse, örgütsel performansın da arttırılabileceğini ifade etmektedir. Etkin bir örgüt kültürünü oluşturmak, örgütün etkinliğini ve performansını arttırmaktadır (Chin, 2002:4). İşletmelerde çalışan işgörenlerin çoğu sahip olunan yapı ve işte çalışmaya isteklidirler. Fakat örgütün bir parçası olan yenilikçi işletmenin yeniliklerin geliştirilmesi için çaba harcamalı, iş tatmini sağlamalı ve yeteneklerini geliştirebilme fırsatı sunmalıdır (Hertog ve Jong, 2007:355; Cunningham ve Higgs, 2009:195).

Bağcı'ya (2009) göre güç, bir kişinin diğer bir kişinin davranışlarını, tutumlarını, fikirlerini, inançlarını, amaçlarını, ihtiyaçlarını ya da sahip olduğu değerlerini değiştirebilme ya da kontrol altına alabilme yeteneğidir. Knights ve Roberts (1982)'nin güç tanımı modern örgütte bireyler ve gruplar arasında karşılıklı bağımlılık ilişkileri olarak tanımlamaktadır (Aydın, 2007). Örgütsel yapı, süreç ve uygulamalar, yöneticilerin politik davranışları, işgörenlerin performanslarını, örgüte olan bağlılıklarını, örgüte karşı niyetlerini ve eylemlerini etkilemektedir. Politik davranışlara bağlı olarak işgörenlerin geliştirdiği tepkiler, iş verimliliği ve örgütsel performansın düşüşüne, yetişmiş iş gücü kaybına, işgörenlerin örgütsel bağlılıklarında azalmaya neden olabilmektedir (Demirel ve Seçkin, 2009:149). Güç vasıtasıyla hareket eden ya da güç yoluyla işleyen organizasyonlarda gücü en iyi anlayan ve kullanan kişilerin başında yöneticiler gelmektedir. Bu yolla yöneticiler, yeniliği ve bilgiyi son derece dinamik, çok boyutlu, etkili ve başarılı bir biçimde kullanmaları ve yönetmeleri gerekmektedir (Bayrak, 2001:27).

Öğrenme, yeni bilgilerin girdisi ve bu bilgilerin çıktısını oluşturmak için, bilgi havuzunu işleme, elde etme, kısa sürede ortaya çıkarma sürecidir (Morales vd., 2009). Öğrenme sürecinin etkin bir şekilde yerine getirilebilmesi için öğrenme düzeylerine önem verilmesi gerekmektedir (Tajeddini, 2009:530). Örgütsel öğrenme, bireylerin gerçekten ulaşmak istedikleri sonuçları ortaya koymak için sürekli kapasitelerini genişlettikleri, yenilikçi düşünme yöntemlerini ortaya koydukları, bütüncül bilincin özgürleştirildiği ve insanların sürekli birlikte öğrenme yöntemlerini kavramayı devam ettirdikleri bir süreç olarak tanımlanmaktadır (Çakıcı, 2006). İşletmelerin yenilik stratejileri uygulamaları için yeniliğe doğrudan cevap vermeleri gerekmektedir. Yeniliğin ve rekabetin hızlı olduğu çevrede işletmelerin varlığını sürdürebilmesinde kıyaslamanın ve örgütsel öğrenme yeteneğinin geliştirilmesinin rolü büyüktür. İşletmelerin diğer işletmelerle işbirliği kurması, örgütlerin ve kurumların yaşamlarını sürdürebilme çabaları açısından önemli bir faktördür (Carlsson, 2006:60).

Hicks'e (1975) göre işletme yapısı, organizasyonda meydana gelen karşılıklı davranışlar bütünüdür. Robbins'e (2000) göre işletme yapısı örgüte ilişkin 
görevlerin biçimsel olarak bölünmesi, gruplanması ve koordine edilmesidir. lyi bir biçimde kurulmamış işletme yapısı, işletmenin faaliyet sürecini ve performansını olumsuz yönde etkileyebilmektedir. Yöneticiler ne kadar iyi olursa olsun bu durumu fark edememektedirler (Drucker, 1996:246). Organizasyonlar küreselleşme süreciyle birlikte pazarda rakiplerine karşı üstünlük sağlamak, örgütsel etkinlik ve hizmet kalitesi gibi amaçlarına ulaşmak için örgüt yapılarını yeniden yapılandırmalı ve bu süreci etkin bir biçimde yönetebilmelidir (Kanbur, 2008).

Literatürde bilgi yönetimi ile örgüt içi dinamiklere ilişkin bazı çalışmalar vardır. Örneğin Liao ve Wu, (2010) bilgi yönetimi, örgütsel öğrenme ve örgütsel yenilik arasındaki ilişkiye yönelik bir çalışma yapmışlardır. Çalışma sonucunda, bilgi yönetiminin önemli bir girdi olduğunu, örgütsel öğrenmenin anahtar bir süreç olduğunu örgütsel yeniliğin ise kritik bir çıktı veya sonuç olduğunu belirlemişlerdir. Öte yandan, Ho, (2009) yapmış olduğu çalışmasında, strateji ve liderliğin bilgi yönetimi üzerine pozitif yönde bir etkisinin bulunduğunu belirtmektedir. Ayrıca, bilgiyi ortaya koyma, bilgiyi içselleştirme ve bu bilgiyi müşteriye sunmanın işletmenin finansal performansı üzerinde önemi bir katkısının olduğunu tespit etmiştir.

\section{ARAŞTIRMANIN YÖNTEMI}

$\mathrm{Bu}$ araştırmanın amacı, bilgi yönetimi ile yenilik arasındaki ilişkide örgüt içi dinamiklerin ara değişkenlik etkisini belirlemektir. Bu amaç çerçevesinde Türkiye'de faaliyet gösteren beş yıldızlı otel işletmeleri araştırmaya dahil edilmiştir. Araştırmanın yöntemi nicel araştırma yöntemine dayanmaktadır. Araştırmada nicel araştırma yöntemi kapsamında anket tekniğinden yararlanılarak veriler toplanmıştır. Bu çalışmada evren, örneklemi oluşturmuştur. Tam sayım yöntemi ile araştırmaya konu olan otel işletmeleri listelenmiştir. Bu işletmeler, ülkemizde faaliyet gösteren 5 yıldızlı turizm yatııım ve işletme belgeli işletmelerdir. Sözü geçen otel işletmeleri, dolayısıyla örneklemi oluşturacak sayı Kültür ve Turizm Bakanlığının yayınlamış olduğu 2010 yllı istatistiklerine göre 349 dur. Bu nedenle araştırmanın örneklemi bu otel işletmelerinde hâlihazırda çalışan 349 adet üst düzey yönetici olarak öngörülmektedir. Araştırma evreninin belirlenmesinde yalnızca 5 yıldızlı otellerin seçilmesinin nedeni ise, bu otellerin daha profesyonel bir biçimde yapılandırılması, koordine edilmesi, yönetilmesi ve kurumsallaşmış olmalarından kaynaklanmaktadır. Araştırma verileri, bahsi geçen otel işletmelerinin birer üst düzey yönetici aracılığı ile elde edilmiştir. Toplamda 321 otel işletmesinden veriler elde edilmiştir. Evren ulaşılabilir büyüklükte olduğu için tam sayım yöntemi kullanılmıştır. Bu nedenle çalışmada, ayrıca bir örnekleme yöntemi kullanılmamıştır.

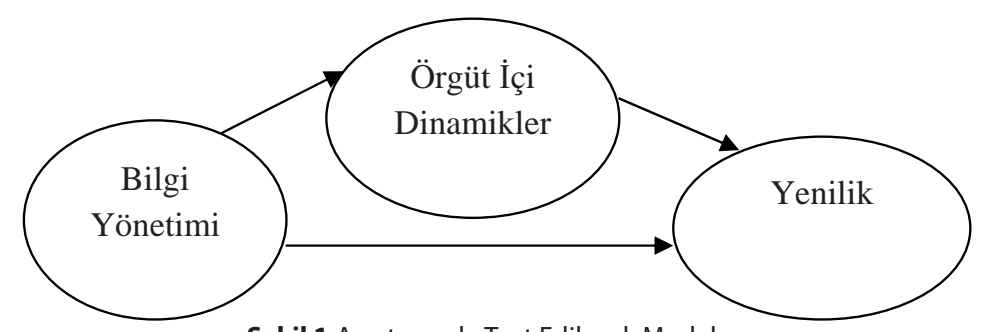

Şekil 1:Araştırmada Test Edilecek Model

Şekil 1'de araştırmaya konu olan değişkenlerin test edilmesi amacıyla iki farklı regresyon modeli görülmektedir. Illk model, bilgi yönetimi ile yenilik arasındaki ilişkiyi test etmek amacıyla kurulmuştur. İkinci model, bilgi yönetimi ile yenilik arasındaki ilişkide örgüt içi dinamiklerin ara değişkenlik etkisini ölçmek amacıyla oluşturulmuştur.

Araştırmada veri toplamak için anket tekniğinden yararlanılmıştır. Bu kapsamda yapılan yazın incelemesi sonrasında bilgi yönetimine ilişkin tutum önermeleri Selimoğlu (2005), örgüt içi dinamiklere ilişkin tutum önermeleri, Genç ve Acuner (2004), Yılmaz (2007), Mimir (2008), Nahma vd., (2003), Sönmez
(2007) ve Avcı vd., (2010) ve son olarak yeniliğe ilişkin tutum önermeleri, Soylu ve Göl (2010), Ulusoy vd., (2008) ve Zona (2009)'nınyapmış oldukları çalışmalardan yararlanılarak anket formu oluşturulmuştur. Geliştirilen bu soru formuna konunun uzmanı iki kişinin (birisi akademisyen diğeri danışman olmak üzere) görüşleri alınarak son şekli verilmiştir. Anket formu dört temel bölümden oluşmaktadır. Illk üç bölümde sırasıyla, yöneticilerin bilgi yönetimine, örgüt içi dinamiklere ve yeniliğe ilişkin tutumlarını belirlemeye yönelik ifadeler yer almakta ve bu ifadeler beşli likert ölçeği ile test edilmektedir.Dördüncü bölümde ise katılımcıların demografik özelliklerini belirlemeye yönelik sorulara yer verilmiştir. 
Soru formu oluşturulduktan sonra ön uygulama gerçekleştirilmiştir. Ön uygulama 25 Mayıs 2011 ve 05 Haziran 2011 tarihleri arasında 30 üst düzey yöneticiye uygulanmıştır. Anket formu uygulatılırken öncelikle konu hakkında bilgi verilmiş sonrasında form yöneticilere bırakılmış ve belli bir süre sonra da toplanmıştır. Daha sonra toplanan anket formundan elde edilen verilerin güvenilirliği ölçülmüş ve ön uygulamada elde edilen verilerin Cronbachalpha değeri 0,87 olarak hesaplanmıştır. Test sonucunda verilerin genel Cronbachalpha'sıNunnally'in (1967) belirttiği 0,7 düzeyinin üzerinde gerçekleşmiştir. Sonrasında anket formu tekrardan konu ile ilgili uzman kişilere inceletilmiş, görüşleri alınmıştır. Elde edilen verilerin analiz edilmesinde Lisrel programından yararlanılmıştır. Verilerden demografik olanlarının analizi için yüzde ve frekans gibi tanımlayıcı istatistik tekniklerinden yararlanılmıştır.

Araştırmanın değişkenlerin her birisi ile ilgili olarak öncelikle SPSS programında keşfedici (exploratry) faktör analizi, sonrasında ise LISREL programı aracıllğı ile doğrulayıı (confirmatory) faktör analizi yapılarak ölçüm modelleri oluşturulmuştur. Ölçüm modelleri oluşturulduktan sonra, değişkenler arasındaki aracılık etkisini ölçmek amacıyla öncelikle hiyerarşik regresyon analizi (Baron ve Kenny Yöntemi) ve sobel testi yapılmış daha sonra ise Lisrel programı aracıllğı ile path analizleri gerçekleştirilmiştir. Araştırmanın bağımsız değişkeni bilgi yönetimi, bağımlı değişkeni yenilik ve ara değişkeni ise örgüt içi dinamiklerdir. Analize başlamadan önce verilerin normal dağılıma sahip olup olmadığına bakılmıştır. Lisrel programında, normal bir dağılım özelliği gösteren veriler için kullanılan kestirim yöntemi En Yüksek Kestirim Yöntemi ya da Genelleştirilmiş En Küçük Kareler Yöntemi; normal dağılıma sahip olmayan verilerde ise, AğırlıkIı En Küçük Kareler ve Robust Maximum Likelihood yöntemleri tercih edilmektedir. Yapılan test sonucunda, verilerin normal dağılmadığı tespit edilmiştir. Bu nedenle araştırmada Ağırlıklı En Küçük Kareler ve Robust Maximum Likelihood yöntemi kullanılmıştır. Bu kapsamda, analize başlamadan önce veriler normalleştirilmiştir.

\section{ARAŞTIRMANIN BULGULARI ve TARTIŞMA}

Geri dönüşümü olan anket sayısı 321 dir. Geri dönüş oranları dikkate alındığında toplanan anketlerin geri dönüş oranı $\% 92,00$ olarak gerçekleşmiştir. Analizi yapılan anket formlarının demografik bulgularına ilişkin sonuçlar aşağıda tablo 1'de görülmektedir. Verilere, frekans ve yüzde analizi uygulanarak ankete katılan yöneticilerin demografik bulgularına ulaşılmıştır.

Tablo 1: Demografik Yapı İle İlgili Sonuçlar $(s=321)$

\begin{tabular}{|c|c|c|c|c|c|c|c|}
\hline $\begin{array}{c}\text { Demografik } \\
\text { Veriler }\end{array}$ & & $\mathrm{F}$ & $\%$ & & & $\mathrm{~F}$ & $\%$ \\
\hline \multirow{3}{*}{ Cinsiyet } & Bayan & 145 & 45,2 & \multirow{9}{*}{$\begin{array}{l}\text { İşletmenizde } \\
\text { çalıştığınız } \\
\text { departmanınız } \\
\text { hangisidir? }\end{array}$} & Önbüro & 49 & 15,3 \\
\hline & Bay & 176 & 54,8 & & Yiyecek-İçecek & 5 & 1,6 \\
\hline & Toplam & 321 & 100,0 & & Muhasebe & 75 & 23,4 \\
\hline \multirow{7}{*}{ Yaş } & $18-24$ & 37 & 11,5 & & Teknik Servis & 1 & ,3 \\
\hline & $25-34$ & 168 & 52,3 & & Kat Hizmetleri & 3 & 9 \\
\hline & $35-44$ & 85 & 26,5 & & Satış Pazarlama & 19 & 5,9 \\
\hline & $45-54$ & 27 & 8,4 & & İnsan Kaynakları & 143 & 44,5 \\
\hline & $55-64$ & 1 & , 3 & & Diğer & 26 & 8,1 \\
\hline & 65 ve üstü & 1 & 3 & & Toplam & 321 & 100,0 \\
\hline & Toplam & 319 & 99,4 & \multirow{7}{*}{$\begin{array}{l}\text { Çalıştığınız } \\
\text { kurumun } \\
\text { işletmeci } \\
\text { firmasının özelliği } \\
\text { hangisidir? }\end{array}$} & Uluslararası Z. & 60 & 18,7 \\
\hline \multirow{5}{*}{$\begin{array}{l}\text { Öğrenim } \\
\text { Durumu }\end{array}$} & Orta Okul & 4 & 1,2 & & Ulusal Zincir & 139 & 43,3 \\
\hline & Lise & 69 & 21,5 & & Şahıs Şirketi & 112 & 34,9 \\
\hline & Ön Lisans & 43 & 13,4 & & Diğer & 2 &, 6 \\
\hline & Lisans & 201 & 62,6 & & Toplam & 313 & 97,5 \\
\hline & Toplam & 317 & 98,8 & & & & \\
\hline \multirow{6}{*}{$\begin{array}{l}\text { Sektörde kaç } \\
\text { yıldır } \\
\text { çalışıyorsunuz? }\end{array}$} & 1 Yıldan az & 7 & 2,2 & & & & \\
\hline & 1-3 Yıl arası & 53 & 16,5 & & & & \\
\hline & 4-7 Yıl arası & 72 & 22,4 & & & & \\
\hline & 8-11 Yıl arası & 56 & 17,4 & & & & \\
\hline & 12 Yıl veÜzeri & 129 & 40,2 & & & & \\
\hline & Toplam & 310 & 96,6 & & & & \\
\hline
\end{tabular}

Tablo 1'de yer aldığı gibi anketi yanıtlayan yöneticilerin 176 tanesi erkek; 145 tanesi kadındır. Bu durumda erkeklerin oranı \% 54,8 iken kadınların oranı $\% 45,2$ şeklindedir. Yöneticilerin yaş gurupları analiz edildiğinde; 37 otel yöneticisi $(\% 11,5)$ 18-24 yaşaralığl; 168 otel yöneticisi $(\% 52,3) 25-34$ yaş aralığl; 85 otel yöneticisi (\%26,5) 35-44 yaş aralığı; 27 otel yöneticisi $(\% 8,4)$ 45-54 yaş aralığı; 1 otel yöneticisi $(\% 3,0)$ 55-64 
yaş aralığı ve son olarak 1 otel yöneticisi ise $(\% 3,0) 65$ ve üstü yaş aralığındadır. Anket formunu dolduran otel yöneticilerinin eğitim durumları incelendiğinde, 4 yöneticinin $(\% 1,2)$ ortaokul mezunu; 69 yöneticinin $(\% 21,5)$ lise mezunu; 43 yöneticinin $(\% 13,4)$ ön lisans mezunu; 201 yöneticinin ise $(\% 62,6)$ üniversite mezunu olduğu belirlenmiştir. Yöneticilerin, sektörde ne kadar süredir çalıştıklarına ilişkin soru analiz edildiğinde, 7 yöneticinin $(\% 2,2) 1$ yıldan az; 53 yöneticinin (\%16,5) 1-3 yıl arası; 72 yöneticinin (\%22,4) 4-7 yıl arası; 56 yöneticinin $(\% 17,4)$ 8-11 yıl; 129 yöneticinin $(\% 40,2)$ ise 12 yıl ve daha uzun süredir çalıştıkları sonucuna ulaşılmıştır. Yöneticilerin çalışmış oldukları departmanlar incelendiğinde, 49 işgörenin $(\% 15,3)$ önbüro; 5 işgörenin $(\% 1,6)$ yiyecek-içecek; 75 işgörenin $(\% 23,4)$ muhasebe; 1 işgörenin $(\% 0,3)$ teknik-servis; 19 işgörenin $(\% 5,9)$ satış pazarlama; 143 işgörenin $(\% 44,5)$ insan kaynakları; 26 işgörenin ise $(\% 8,1)$ farklı departmanlarda çalıştıkları tespit edilmiştir. Otel işletmelerin işletme finansman özeliğine göre, 60 işletme $(\% 18,7)$ uluslar arası zincir; 139 işletme $(\% 43,3)$ ulusal zincir; 112 işletme $(\% 34,9)$ şahıs şirketi; 2 işletme $(\% 0,6)$ ise diğer finansman özelliğine sahip oldukları belirlenmiştir.

\subsection{Bilgi Yönetimi Ölçeğine illişkin Bulgular}

Bilgi yönetimi ölçeğinin test edilmesinde doğrulayıcı faktör analizi kullanılmıştır. Doğrulayıcı faktör analizi açıklayıcı faktör analiz modelinin bir uzantısıdır. Doğrulayıcı faktör analizi(DFA) gizil değişkenler (faktörler) ile gözlenen ölçümler (değişken) arasındaki ilişkileri ölçmeye olanak sağlayan YEM'in bir türüdür (Yılmaz ve Çelik, 2009). Bilgi yönetimini oluşturan boyutların gözlenen değişkenlerin stan- dartlaştırılmış yükleri aşağıdaşekil 2'de görülmektedir. Analiz sonucunda, bilgi yönetimi 3 boyuttan oluşmuştur. Bu boyutlar bilgiyi değerlendirme (D), bilgiyi içselleştirme (I) ve bilginin elde edilmesidir (E). Bilgiyi değerlendirme boyutunu (D) oluşturan gözlenen değişkenler, D1(çalışanlar sahip oldukları bilgiyi, işlerini geliştirmek için hiç tereddüt etmeden kullanmakta), D2 (bilgi kullanımının en önemli katkısı tüm departmanların hizmet yeteneğini geliştirilmesine yöneliktir), D3 (çalışanlar geçmiş deneyimler ile organizasyon dışında öğrendiklerini geliştirerek yeni fikirleri işlerine uygulamakta), D4 (bilgi yönetim uygulamaları sayesinde tüm departmanın genel performansı artmakta), D5 (bilgi kaynaklarından yararlanabilmek için bilgiyi uygulama alanlarına aktarılmakta), D6 (çalışanların ihtiyaç duydukları bilgiye her an ulaşabilirler)dır. Bilgiyi içselleştirme boyutunu (I) oluşturan gözlenen değişkenler, I1 (bilginin saklanması için gerekli veritabanı oluşturulmakta), 12 (işletme içerisindeki bilgi sürekli olarak güncellenmekte), I3 (İşletmede, herkese açık olan bilgilerin erişimi için farklı yöntemler kullanılmakta), 14 (bilgi yönetimine ilişkin kaynaklar tüm çalışanlara paylaşılmakta) şeklindedir.Son olarak, Bilgiyi elde etme boyutunu (E) oluşturan gözlenen değişkenler ise, E1 (çalışanlar istedikleri bilgiyi genellikle saha çalışmalarından elde etmekte), E2 (çalışanlar kendi tecrübeleri ile ilgili deneyimlerini rutin olarak depolamakta), E3 (İşletmede, dışarıdan sağlanan hizmetlerle yeni bilgilerin elde edilmesi sağlanmakta), E4 (yenilikçi fikirleri hayata geçirmek için sürekli olarak yeni bilgiler ortaya konulmakta), E5 (bilginin geliştirilmesine ilişkin yeni fikirler üretilmekte)dir.

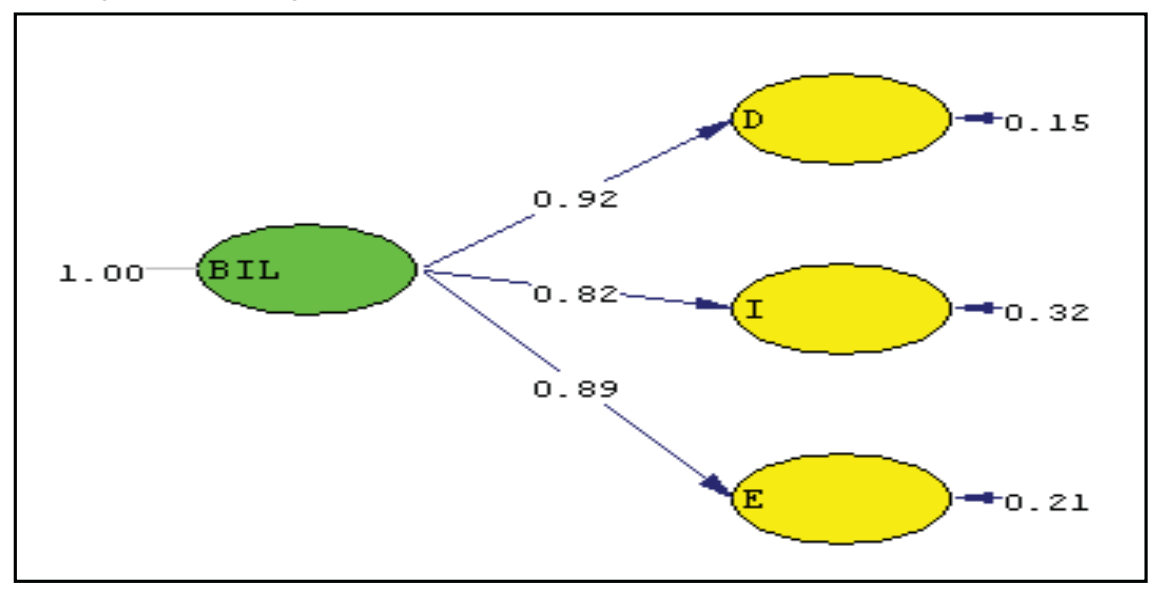

Chi-Square $=112.88, \quad \mathrm{df}=85, \mathrm{P}$-value $=0.02326, \quad \mathrm{RMSEA}=0.032$

Şekil 2: Bilgi Yönetimi İkinci Düzey DFA İçin Üretilen Diyagram ve Standardize Çözüm Değerleri 
Modelde görüldüğü üzere $p$ değeri 0.02326 dır. Bu değer .05 düzeyinde anlamlı olduğunu göstermektedir. Doğrulayıcı faktör analizinde $\mathrm{X}^{2}$, serbestlik derecesine $(\mathrm{sd})$ oranlanarak değerlendirmeye tabi tutulmaktadır. Bu bağlamda bu değerler bir birine oranlandığında, $\left(x^{2}=112.88 /\right.$ $\mathrm{sd}=85)$ sonucun $\mathrm{X}^{2} / \mathrm{sd}=1.33$ olduğu görülmektedir. $x^{2} /$ sd oranının 3 olması kabul edilebilir bir uyuma, 2 olması ise iyi uyuma karşılık gelmektedir. Yapılan analiz sonucunda $x^{2} / s d=1.33$ oranın iyi uyum değeri verdiği anlaşılmaktadır. RMSEA'nın .05'ten küçük olması iyi uyuma, .08'den küçük olması ise ise kabul edilebilir bir uyuma işaret etmektedir. Bu bağlamda yapılan analiz onucunda elde edilen uyum değerinin RMSEA $=0.032$ olduğu tespit edilmiştir. Analiz sonucunda ortaya çıkan RMSEA uyum değerinin. 05'den küçük olduğu için elde edilen uyum değerinin iyi bir uyuma sahip olduğu ifade edilebilir.

Analizde, iyi bir ölçme modeli elde etmek için bu modele modifikasyon(düzeltme indislerine)'dan yararlanılmıştır. Şekil 2'de üst düzey bir örtük (gizil) değişken olan bilgi değişkeni (BIL) D (bilgiyi değerlendirme), I (bilgiyi içselleştirme) ve E (bilgiyi elde etme) değişkenlerini açıklamaktadır. Bu değişkenler arasındaki ilişkiler incelendiğinde D'nin standardize edilmiş değeri $.92\left(R^{2}=0.85\right)$, I'nın standardize edilmiş değeri $.82\left(R^{2}=0.67\right)$ ve $E^{\prime}$ nin standardize edilmiş değeri ise $.89\left(R^{2}=0.79\right)$ dir. Bu sonuçlara göre bilgi yönetimin ikinci düzey değişkenler içerinde en çok $D$ faktörünü, daha sonra $E$ faktörünü ve son olaraktal faktörünü açıkladığı tespit edilmiştir. Bilgi yönetimin ikinci düzey değişkenlerin (faktörlerinin) t-değerlerine bakıldığında, D'nin t-değeri 9.96, I'nın t-değeri 8.14 ve E'nin t-değeri ise 4.89 olduğu hesaplanmıştır. T-değerleri 1.96'yı aşarsa .05 düzeyinde, 2.56'yı aşarsa .01 düzeyinde manidardır (Çokluk vd., 2010). Bu bağlamda t-değerleri incelendiğinde tüm değerlerin .01 düzeyinde anlamlı olduğu tespit edilmiştir.

Tablo 2: Bilgi Yönetimi İkinci Düzey Modeli İçin Ortaya Çıkan Uyum Ölçütleri

\begin{tabular}{|c|c|c|}
\hline Uyum Ölçüsü & Değeri & Uyum \\
\hline $\mathrm{X}^{2} /$ sd & 1.33 & İyi Uyum \\
\hline $\mathrm{RMSEA}$ & 0.032 & İyi Uyum \\
\hline $\mathrm{SRMR}$ & 0.038 & İyi Uyum \\
\hline $\mathrm{NFI}$ & 0.960 & İyi Uyum \\
\hline $\mathrm{NNFI}$ & 0.990 & İyi Uyum \\
\hline $\mathrm{CFI}$ & 0.990 & İyi Uyum \\
\hline $\mathrm{GFI}$ & 0.960 & İyi Uyum \\
\hline $\mathrm{AGFI}$ & 0.940 & İyi Uyum \\
\hline $\mathrm{PGFI}$ & 0.680 & İyi Uyum \\
\hline
\end{tabular}

Tablo 2'de ölçüm modelinin uyum ölçütleri görülmektedir. Buna göre tüm uyum ölçütlerinin iyi uyuma sahip olduğu belirlenmiştir. "Tablo'da yer almayan uyum ölçütlerinden biri de araştırma örnekleminin yeterliliğinin değerlendirildiği kritik N (CN) değeridir. YEM'de 200 ve daha üstü bir değer kritik N istatistiği açısından yeterli bir model uygunluğunun göstergesi olarak kabul edilmektedir (Yılmaz ve Çelik, 2009)". Bu ölçüm modelinin kritik değeri 330.11 olarak belirlenmiştir. Bu araştırmada kullanılan 321 birimlik örneklem için yeterli olduğu ifade edilebilir.

\section{2. Örgüt İçi Dinamikler Ölçeğine ilişskin Bulgular}

Örgüt içi dinamikler ölçeğinin test edilmesinde doğrulayıcı faktör analizi kullanılmıştır. Doğrulayıcı faktör analizi açıklayıcı faktör analiz modelinin bir uzantısıdır.Örgüt içi dinamikleri oluşturan boyutların gözlenen değişkenlerin, aşağıda şekil 3'de görülmektedir. Analiz sonucunda, örgüt içi dinamik ölçeği 5 boyuttan oluşmuştur. Bunlar, İşletme Yapısının İşleyişi (IY), Örgüt Kültürü (OK), Liderlik (L), Güç ve Politika (GP) ve Örgütsel Öğrenme (OG) dir. İşletme yapısının işleyiş boyutunu (IS) oluşturan gözlenen değişkenler, IY1 (kararlar, üst yönetim seviyesinde alınmaya yöneliktir), IY2 (işler çalışanların yeteneklerine göre uzmanlık alanlarına bölünmüştür), IY3 (tüm personelin kademe farklılıkları açık-seçik olarak belirlenmiştir), IY4 (çalışanların yapacakları işlerde uygulayacakları kurallar, davranış şekilleri ayrıntılı bir şekilde belirlenmiştir) şeklindedir. Örgüt kültürü boyutunu (OK) oluşturan gözlenen değişkenler, OK1 (tüm işgörenler, değişen pazar koşullarına karşı hızlı yanıt vermeye çalışırlar), OK2 (bilgi açık bir şekilde paylaşılmakta), OK3 (değişime önem verilmekte)dir. Liderlik boyutunu (L) oluşturan gözlenen değişkenler, L1 (lider görevlerin yürütüleceği yolları açıklar), L2 (lider işlerlin nasıl yapılacağına karar verir), L3 (lider belirlenen performans standartlarını devam ettirir), L4 (lider astların fikirlerine değer verir) şeklindedir. Güç ve politika boyutunu (GP) oluşturan gözlenen değişkenler, GP1 (tüm çalışanlarla bir beraberlik oluşturarak işletmenin güçlenmesi sağlanmaktadır), GP2 (belirli kurallara önem verilmekte), GP3 (çalışan bağlılığını sağlama da güçlendirmenin rolü büyüktür), GP4 (yapılan faaliyetler üst yönetimin kontrolü ile gerçekleşmektedir) dür. Örgütsel Öğrenme boyutunu (OG) oluşturan gözlenen değişkenler, OG1 (çalışanlar kendilerini geliştirme konularında motive edilir), OG2 (bireyler düşüncelerini ifade etmede açık fikirli olmaya özendirilir), OG3 (tüm çalışanlar işletme içerinde doğabilecek sorunların çözümüne karşı sürekli teşvik edilir) şeklindedir. 


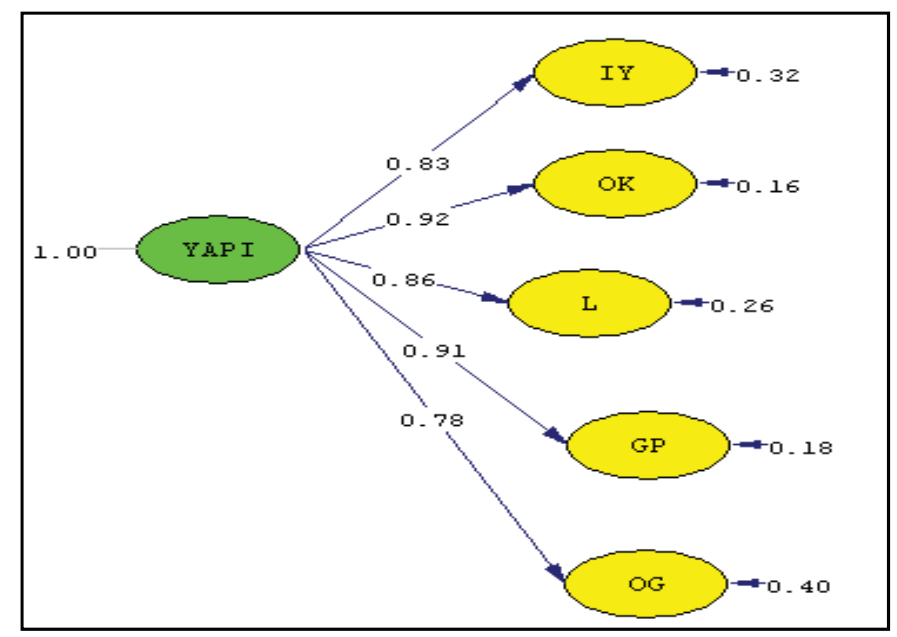

Chi-Square $=278.98, \quad \mathrm{df}=130, \mathrm{P}$-value $=0.00000, \quad \mathrm{RMSEA}=0.060$

Şekil 3: Örgüt İçi Dinamikler Ölçeğine Illişkin İkinci Düzey DFA İçin Üretilen Diyagram ve Standardize Çözüm Değerleri

Modelde görüldüğü üzere $p$ değeri 0.00000dir. Bu değer .01 düzeyinde anlamlı olduğunu göstermektedir. Analize devam edildiğinde, $X^{2} / \mathrm{sd}\left(x^{2}=278.98 /\right.$ $s d=130)$ değerinin 2.15 olduğu görülmektedir. Yapılan analiz sonucunda $x^{2} / s d=2.15$ oranın iyi uyum değeri verdiği anlaşılmaktadır. Analiz sonucunda elde edilen uyum değerinin $\mathrm{RMSEA}=0.060$ olduğu ve bu değerin kabul edilebilir bir uyuma sahip olduğu ifade edilebilir.

Şekil 3'de üst düzey bir örtük (gizil) değişken olan örgüt içi dinamikler değişkeni (YAPI), İşletme Yapısının İşleyişi (IY), Örgüt Kültürü (OK), Liderlik (L), Güç ve Politika (GP) ve Örgütsel Öğrenme (OG) değişkenlerini açıklamaktadır. Bu değişkenler arasındaki ilişkiler incelendiğinde IY'nin standardize edilmiş değeri .83 $\left(R^{2}=0.69\right)$, OK'ninstandardize edilmiş değeri .92 $\left(R^{2}=0.85\right)$, L'nin standardize edilmiş değeri $.86\left(R^{2}=0.74\right), G P^{\prime}$ ninstandardize edilmiş değeri .91 $\left(R^{2}=0.83\right)$ ve OG'ninstandardize edilmiş değeri ise .78 $\left(R^{2}=0.61\right)$ dir. Bu sonuçlara göre örgüt içi dinamiklerin ikinci düzey değişkenleri içerinde en çok OK faktörünü, sonra GP faktörünü, sonra $L$ faktörünü, daha sonra IY faktörünü ve son olarakta OG faktörünü açıkladığı tespit edilmiştir.Örgüt içi dinamiklerin ikinci düzey değişkenlerin (faktörlerin) t-değerlerine bakıldığında, IY'nin t-değeri 3.09, OK'nint-değeri 7.64, L'nin t-değeri 8.15, GP'nin t-değeri 10.46 ve OG'nin t-değeri 9.70 olduğu hesaplanmıştır. T-değerleri incelendiğinde tüm değerlerin .01 düzeyinde anlamlı olduğu tespit edilmiştir.

Tablo 3'de ölçüm modelinin uyum ölçütleri görülmektedir. Buna göre uyum ölçütlerinin iyi ve kabul edilebilir bir uyuma sahip olduğu belirlenmiştir. Bu
Tablo 3: Örgüt İçi Dinamikler Ölçeğinin İkinci Düzey Modeli İçin Ortaya Çıkan Uyum Ölçütleri

\begin{tabular}{|c|c|c|}
\hline Uyum Ölçüsü & Değeri & Uyum \\
\hline$X^{2} /$ sd & 2.15 & Kabul Edilebilir \\
\hline RMSEA & 0.060 & Kabul Edilebilir \\
\hline SRMR & 0.052 & Kabul Edilebilir \\
\hline NFI & 0.940 & Kabul Edilebilir \\
\hline NNFI & 0.960 & Kabul Edilebilir \\
\hline CFI & 0.970 & İyi Uyum \\
\hline GFI & 0.910 & Kabul Edilebilir \\
\hline AGFI & 0.880 & Kabul Edilebilir \\
\hline PGFI & 0.690 & Kabul Edilebilir \\
\hline
\end{tabular}

ölçüm modelinin kritik değeri 195.74 olarak tespit edilmiştir. Bu araştırmada kullanılan 321 birimlik örneklem için yeterli olduğu ifade edilebilir.

\subsection{Yenilik Ölçeğine İlişkin Bulgular}

Yenilik ölçeğinin test edilmesinde doğrulayıcı faktör analizi kullanılmıştır. Doğrulayıcı faktör analizi açıklayıcı faktör analiz modelinin bir uzantısıdır. Yeniliği oluşturan boyutların gözlenen değişkenlerin standartlaştırılmış yükleriaşağıda şekil 4'de görülmektedir. Analiz sonucunda, yenilik ölçeği 6 boyuttan oluşmuştur. Bu boyutlar Stratejik Yenilik (ST), İş Modelleri Yeniliği (IS), Deneyim Yeniliği (DE), Süreç Yeniliği (SU), Pazarlama Yeniliği (PA) ve Ürün Yeniliği (UR) dir. Stratejik yenilik boyutunu (ST) oluşturan gözlenen değişkenler, ST1 (yeniliği geliştirmede yenilik stratejileri kullanılmakta), ST2 (pazarın yapısına bağlı olarak farklı yenilik stratejileri uygulamakta), ST3 (rakiplerin yapmış oldukları yenilikler yakından takip edilmekte) şeklindedir. İş modelleri yeniliğini (IS) oluşturan gözlenen değişkenler, IS1 (kullandığımız iş modeli sayesinde ortaya konulan ürünler pazardaki değişimlere karşı güçlü bir değer oluştur- 
makta), IS2 (yeni yollarla müşterilerin ihtiyaçlarına cevap verecek yeni iş modelleri tasarlanmakta, IS3 (rakiplerimizi sürekli olarak iyi anlayabilmek için iş modellerimizin güçlenmesine önem verme), IS4 (kullandığımız iş modeli faaliyet gösterdiğimiz sektörde önemli bir yere sahip) dür. Deneyim yeniliği boyutunu (DE) oluşturan gözlenen değişkenler, DE1 (geçmiş deneyimlerden yararlanarak kalite yönetim sistemini yenilemekte), DE2 (geçmiş deneyimlere bağlı olarak firma içi bilgi paylaşım sistemini yenilemekte), DE3 (geçmiş deneyimlere bağlı olarak departmanlar arası koordinasyonu kolaylaştırmaya yönelik çalışmalar yenilemekte), DE4 (geçmiş deneyimlere bağlı olarak takım çalışmasını kolaylaştırmaya yönelik organizasyon yapısını yenilemekte) şeklindedir. Süreç yeniliği boyutunu (SU) oluşturan gözlenen değişkenler, SU1 (üretim süreçlerinde çıktı kalitesini arttırıcı yenilikler yapılmakta), SU2 (teslimatla ilgili süreçlerde değer katmayan faaliyetler ayıklanmakta), SU3 (mevcut ürünlerin çıktı maliyetini azaltıcı yenilikler yapılmakta)şeklindedir. Pazarlama yeniliği boyutunu (PA) oluşturan gözlenen değişkenler, PA1 (yeni ürünlerin tanıtımında kullanılan reklam, müşteriye özel tanıtımlar, yeni marka sembolleri, vs. gibi yeni promosyon tekniklerinin geliştirilmekte), PA2 (yeni ürünlerin fiyatlandırılmasında talebe, maliyete, marka imajına, müşteri grubuna göre, vs., yeni fiyatlama tekniklerinin geliştirilmekte), PA3 (genel pazarlama faaliyetleri yenilenmekte), PA4 (pazardaki değişimleri yönetebilmeye önem verilmekte) şeklindedir. Ürün yeniliği boyutunu (UR) oluşturan gözlenen değişkenler, UR1 (üretim süreçlerinde değer katmayan faaliyet adımları ayıklanmakta), UR2 (üretim süreçlerinde değişken maliyetleri azaltıcı yenilikler yapılmakta), UR3 (mevcut ürünlerden tamamen farklı işlevsel özelliklere sahip yeni ürünler piyasaya sunulmakta) şeklindedir.

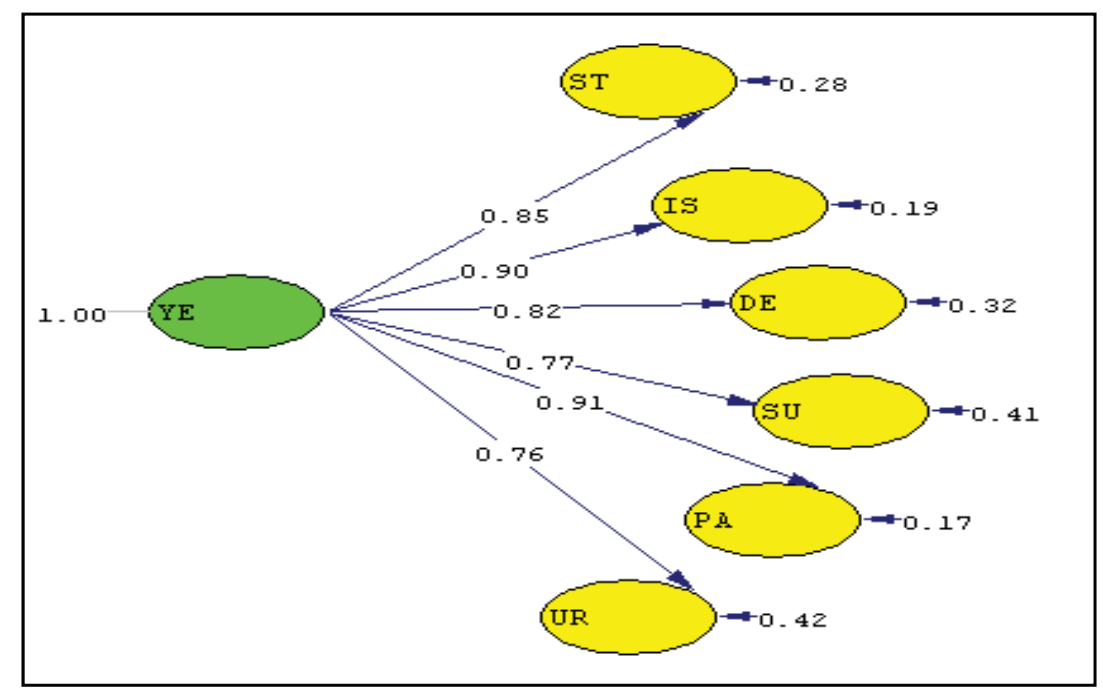

Chi-Square=333.28, $d f=181$, P-value $=0.00000, \quad$ RMSEA $=0.051$

Şekil 4: Yenilik Ölçeğine İlişkin İkinci Düzey DFA İçin Üretilen Diyagram ve Standardize Çözüm Değerleri

Modelde görüldüğü üzere p değeri 0.00000dir. Bu değer .01 düzeyinde anlamlı olduğunu göstermektedir. Analize devam edildiğinde, $x^{2} / s d\left(x^{2}=333.28 /\right.$ $s d=181)$ değerinin 1.84 olduğu görülmektedir. Yapılan analiz sonucunda $x^{2} / s d=1.84$ oranın iyi uyum değeri verdiği anlaşılmaktadır. Analiz sonucunda elde edilen uyum değerinin RMSEA=0.051 olduğu ve bu değerin kabul edilebilir bir uyuma sahip olduğu ifade edilebilir.

Şekil 4'de üst düzey bir örtük (gizil) değişken olan yenilik değişkeni (YE) Stratejik Yenilik (ST), İş Modelleri Yeniliği (IS), Deneyim Yeniliği (DE), Süreç Yeniliği (SU), Pazarlama Yeniliği (PA) ve Ürün Yeniliği
(UR) değiş̧kenlerini açıklamaktadır. Bu değişkenler arasındaki ilişkiler incelendiğinde ST'nin standardize edilmiş değeri $.85\left(R^{2}=0.72\right)$, IS'ninstandardize edilmiş değeri .90 $\left(R^{2}=0.81\right)$, DE'ninstandardize edilmiş değeri .82 $\left(R^{2}=0.67\right)$, SU'nunstandardize edilmiş de-

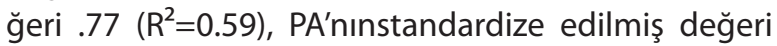
$.91\left(R^{2}=0.83\right)$ ve UR'ninstandardize edilmiş değeri ise $.76\left(R^{2}=0.58\right)$ dir. Bu sonuçlara göre yenilik ölçeğinin ikinci düzey değişkenler içerinde en çok PA faktörünü, sonra IS faktörünü, sonra ST faktörünü, sonra DE faktörünü, daha sonra SU faktörünü ve son olarakta UR faktörünü açıkladığını tespit edilmiştir. Yenilik ölçeğinin ikinci düzey değişkenlerin (faktörlerin) 
t-değerlerine bakıldığında, ST'nin t-değeri 13.57, IS'nint-değeri 10.79,DE'nint-değeri 8.37, SU'nun t-değeri 10.28, PA'nın t-değeri 9.71 ve UR'nin t-değeri 7.22 olduğu hesaplanmıştır.T-değerleri incelendiğinde tüm değerlerin .01 düzeyinde anlamlı olduğu tespit edilmiştir.

Tablo 4: Yenilik Ölçeğinin İkinci Düzey Modeli Iç̧in Ortaya Çıkan Uyum Ölçütleri

\begin{tabular}{|c|c|c|}
\hline Uyum Ölçüsü & Değeri & Uyum \\
\hline $\mathrm{X}^{2} / \mathrm{sd}$ & 1.84 & İyi Uyum \\
\hline $\mathrm{RMSEA}$ & 0.051 & İyi Uyum \\
\hline SRMR & 0.052 & Kabul Edilebilir \\
\hline $\mathrm{NFI}$ & 0.950 & İyi Uyum \\
\hline $\mathrm{NNFI}$ & 0.970 & İyi Uyum \\
\hline $\mathrm{CFI}$ & 0.980 & İyi Uyum \\
\hline $\mathrm{GFI}$ & 0.910 & Kabul Edilebilir \\
\hline $\mathrm{AGFI}$ & 0.880 & Kabul Edilebilir \\
\hline $\mathrm{PGFI}$ & 0.710 & İyi Uyum \\
\hline
\end{tabular}

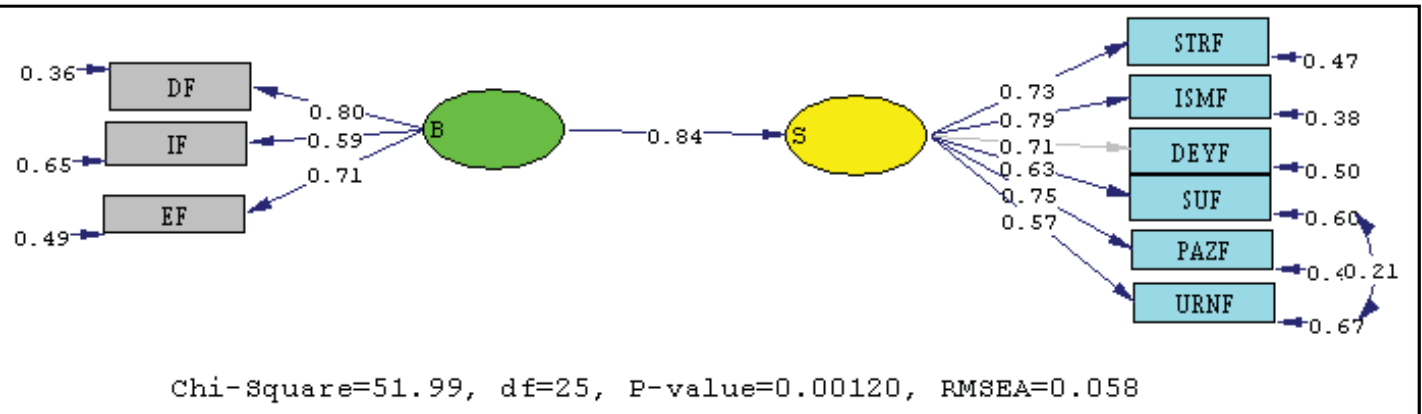

Şekil 5: Bilgi Yönetimi ve Yenilik Ölçüm Modeline İçin Üretilen Diyagram ve Standardize Çözüm Değerleri

Modelde görüldüğü üzere $p$ değeri 0.00120dir. Bu değer 05 düzeyinde anlamlı olduğunu göstermektedir. Analize devam edildiğinde, $X^{2} / s d\left(X^{2}=51.99 /\right.$ $\mathrm{sd}=25)$ değerinin 2.07 olduğu görülmektedir. Yapılan analiz sonucunda $x^{2} / s d=2.07$ oranın iyi uyum değeri verdiği anlaşılmaktadır. Analiz onucunda elde edilen uyum değerinin $\mathrm{RMSEA}=0.058$ olduğu ve bu değerin kabul edilebilir bir uyuma sahip olduğu ifade edilebilir.

Tablo 5'de ölçüm modelinin uyum ölçütleri görülmektedir. Buna göre uyum ölçütlerinin iyi ve kabul edilebilir bir uyuma sahip olduğu belirlenmiştir. Öte yandan, bu ölçüm modelinin kritik değeri 249.95 olarak belirlenmiştir.

Bilgi yönetimi, örgüt içi dinamikler ve yenilik ölçeğinin test edilmesinde yapısal eşitlik modeli kullanıl-
Tablo 4'de ölçüm modelinin uyum ölçütleri görülmektedir. Buna göre uyum ölçütlerinin iyi ve kabul edilebilir bir uyuma sahip olduğu belirlenmiştir. Bu ölçüm modelinin kritik değeri 218.71 olarak tespit edilmiştir. Bu araştırmada kullanılan 321 birimlik örneklem için yeterli olduğu ifade edilebilir.

Bilgi yönetimi ve yenilik ölçeğinin test edilmesinde yapısal eşitlik modeli kullanılmıştır. Analize geçmeden önce hipotez belirlenmiştir.

$\mathrm{H}_{1}$ : Bilgi yönetimi, yeniliği pozitif yönde etkilemektedir.

Şekil 5'de modelde değişkenler arasındaki ilişkilere bakıldığında bilgi yönetimi (B) yeniliği (S) pozitif yönde etkilediği görülmektedir. Bu sonuca bağlı olarak $\mathrm{H}_{1}$ kabul edilmiştir. Bilgi yönetimin (B) yeniliğe (S) etkisine ilişkin standardize edilmiş çözüm değeri 0.84 tür. Ölçüm modelin t-değerlerine bakıldığında, bilgi yönetimin (B) yenilik (S) üzerindeki t-değeri ise 11.46dır. Bu bağlamda, t-değerinin anlamlı olduğu tespit edilmiştir. 


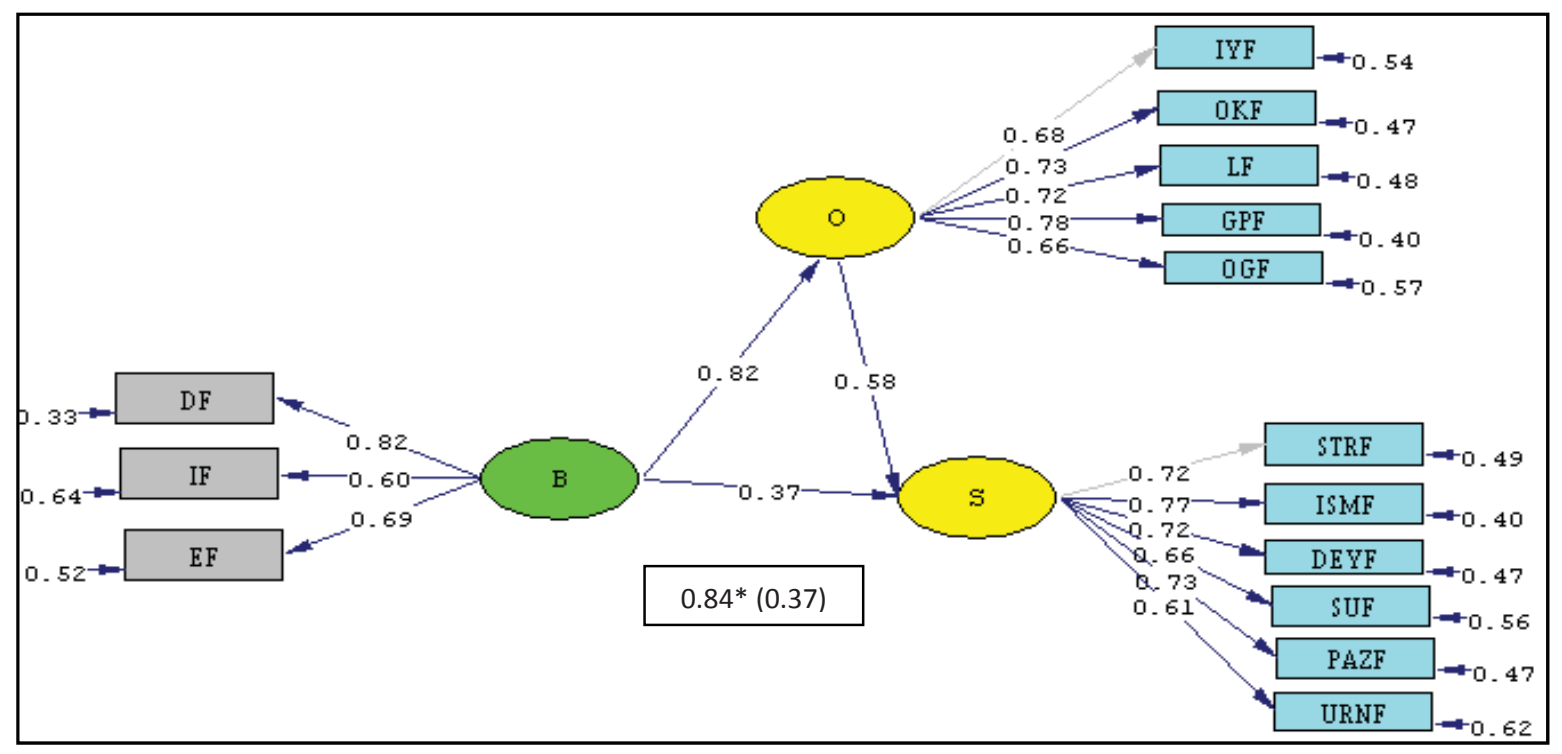

Chi-Square $=177.42, \quad \mathrm{df}=74, \quad P$-value $=0.00000, \quad \mathrm{RMSEA}=0.066$

Şekil 6: Bilgi Yönetimi, Yenilik ve Örgüt Iç̧i Dinamikler Modeli Için Üretilen Diyagram ve Standardize Çözüm Değerleri

Şekil 6'da modelde değişkenler arasındaki ilişkilere bakıldığında bilgi yönetimi (B) ile yenilik (S) arasında örgüt içi dinamiklerin (O) kısmi aracı etkiye sahip olduğu görülmektedir. Bu sonuca bağlı olarak $\mathrm{H}_{2}$ kabul edilmiştir. Bilgi yönetimi (B) ile yenilik (S) arasında örgüt içi dinamiklerin (O) kısmi aracılık etkisine ilişkin standardize edilmiş çözüm değerleri . $82+$ $.58\left(R^{2}=0.67+0.34\right)$ dir. Ölçüm modelin t-değerlerine bakıldığında, bilgi yönetimi (B) ile yenilik (S) arasında örgüt içi dinamiklerin (O) kısmi aracılık etkisine ilişkin t-değerleri $10.81+5.29$ olduğu hesaplanmıştır. Bu bağlamda, t-değerinin anlamlı olduğu tespit edilmiştir.Modelde görüldüğü üzere $p$ değeri 0.00000dir. Bu değer .01 düzeyinde anlamlı olduğunu göstermektedir. Analize devam edildiğinde, $X^{2} / s d\left(x^{2}=177.42 /\right.$ $\mathrm{sd}=74$ ) değerinin 2.39 olduğu görülmektedir. Yapılan analiz sonucunda $x^{2} / s d=2.39$ oranın kabul edilebilir bir iyi uyum değeri verdiği anlaşılmaktadır. Analiz sonucunda elde edilen uyum değerinin RMSEA $=0.066$ olduğu ve bu değerin kabul edilebilir bir uyuma sahip olduğu ifade edilebilir.

Tablo 6'da ölçüm modelinin uyum ölçütleri görülmektedir. Buna göre uyum ölçütlerinin iyi ve kabul edilebilir bir uyuma sahip olduğu belirlenmiştir. Ayrıca, bu ölçüm modelinin kritik değeri 190.25 olarak belirlenmiştir.
Tablo 6: Bilgi Yönetimi, Yenilik ve Örgüt İçi Dinamikler Modeli İçin Ortaya Çıkan Uyum Ölçütleri

\begin{tabular}{|c|c|c|}
\hline Uyum Ölçüsü & Değeri & Uyum \\
\hline$X^{2} /$ sd & 2.39 & Kabul Edilebilir \\
\hline RMSEA & 0.066 & Kabul Edilebilir \\
\hline SRMR & 0.040 & İyi Uyum \\
\hline NFI & 0.097 & İyi Uyum \\
\hline NNFI & 0.098 & İyi Uyum \\
\hline CFI & 0.098 & İyi Uyum \\
\hline GFI & 0.093 & Kabul Edilebilir \\
\hline AGFI & 0.090 & İyi Uyum \\
\hline PGFI & 0.065 & İyi Uyum \\
\hline
\end{tabular}

\section{SONUÇ ve ÖNERILER}

Araştırma sonuçlarına göre literatürde olduğu gibi bilgi yönetimi ile yenilik arasında güçlü bir ilişkinin olduğu tespit edilmiştir. Fakat sonraki aşamada, bu araştırmanın özgünlüğünü ortaya koyan örgüt içi dinamiklerin aracı değişken olup olmadığı araştırılmış ve örgüt içi dinamiklerin bilgi yönetimi ile yenilik arasındaki ilişkiyi anlamlı düzeyde kendisine çektiği görülmüştür. Bu bulgudan hareketle örgüt içi dinamiklerin, bilgi yönetimi ve yenilik arasındaki ilişkiyi tamamen ortadan kaldırmadığı için kısmi ara değişken etkisine sahip olduğu söylenebilir.

Yapılan analiz sonucunda, bilgi yönetimi üç faktör altında toplanmıştır. Bu faktörler, bilgiyi içselleştirme, bilgiyi elde etme ve bilgiyi değerlendirmedir. Ayrıca, bu faktörler içerisinde öncelikli olarak otel yöneticilerin önem verdikleri faktörler sırası ile bilgiyi değerlendirme, bilgiyi elde etme ve bilgiyi içselleştirmedir. Literatürde genellikle bilgi yönetim süreci, bilginin 
elde edilmesi, bilginin içselleştirilmesi, bilginin paylaşılması ve bilginin değerlendirilmesi şeklindedir. Otel işletmelerinde bilginin değerlendirilmesinin stratejik bir önemi vardır. Stratejik olarak değerlendirilen bilgi otel işletmelerine rekabet avantajı kazandırmaktadır. $\mathrm{Bu}$ durum aynı zamanda otel işletmesinin performansının artmasına da katkıda bulundurabilmektedir (Yılmaz, 2009). Bilginin paylaşılması öğrenen bir örgüt için gerekli unsurdur. Ayrıca çağın gösterdiği gelişmelere bağlı olarak otel işletmelerinin öğrenen örgüt olabilmeleri için bilgiyi üretmeli ve bu bilgiyi paylaşma konusunda da paylaşımcı olabilmelidirler. Çünkü bilgi paylaşıldıkça değer kazanmaktadır. Bu nedenle yöneticilerin bilginin paylaşılmasına önem vermeleri gerekmektedir.

Araştırmada yapılan analiz sonucunda, yenilik altı faktör altında toplanmıştır. Bu faktörler, stratejik yenilik faktörü, deneyim yeniliği faktörü, iş modeli faktörü, süreç yeniliği faktörü, ürün yeniliği faktörü ve pazarlama yeniliği faktörüdür. Ayrıca, bu faktörler içerisinde öncelikli olarak otel yöneticilerin önem verdikleri faktörler sırası ile pazarlama yeniliği, iş modeli yeniliği, stratejik yenilik, deneyim yeniliği, süreç yeniliği ve ürün yeniliğidir. Yöneticilerin özellikle yenilik kapsamında pazarlama yeniliğine önem verdikleri anlaşılmıştır. Bazı işletmeler sektörün yapısına bağlı olarak artımsal yeniliği benimseyeceği gibi bazı işletmelerde radikal yeniliği benimseyebilirler. Radikal yenilikte ürün yeniliği ve stratejik yenilik önemli unsur iken; artımsal yenilikte iş modelleri ve süreç yeniliği gibi faktörlerin öne çıktığı görülmektedir. Bu kapsamda her otel işletmesi kendi pozisyonuna göre bir pozisyon almalı ve bu pozisyonu etkin bir biçimde yönetmelidir. Etkili strateji kadar, yenilik ve bilgi tabanlı rekabet işletmeler için önemli bir değerdir. Bu nedenle, bilgi ve yenilik işletmelerin sürdürülebilir rekabet avantajı için kritik kaynaklarıdır (Xu ve diğ., 2010). Yenilikçi işletmelerin yenilik için gerekli bilgi ve enformasyonu dışarıdan elde edebilecek ve işletme içerisinde bunları yeniliğe dönüştürebilecek daha esnek bir yapıya sahip olması gereklidir. Çünkü yenilik fikirlerinin ortaya çıkarılması ve işletmede çalışanlar tarafından paylaşılması fikirlerin kolayca tartışılabildiği daha esnek bir yapının gerekliliğini zorunlu kıldığı görülmektedir (Uzkurt, 2010).

Yapılan analiz sonucunda, örgüt içi dinamikleri temsil eden örtük değişken; işletme yapısının işleyişi, liderlik, örgüt kültürü, güç/politika ve örgütsel öğrenme örtük değişkenidir. İşletme yapısının işleyişi, dört gözlenen değişken tarafından; liderlik dört gözlenen değişkenle; örgüt kültürüüç gözlenen değişkenle; güç/politika dört gözlenen değişkenle ve son olarak örgütsel öğrenme örtük değişkeni ise üç gözlenen değişken tarafından temsil edilmektedir. Öte yandan bu örtük değişkenler içerisinde otel yöneticilerinin öncelikli olarak önem verdikleri örtük değişkenler sırası ile örgüt kültürü, güç/politika, liderlik, işletme yapısının işleyişi ve örgütsel öğrenmedir. Kültür, bir örgütün içindeki birey ve grupların davranışlarını yönlendiren normlar, davranış kalıpları, inançlar, tutum ve alışkanlıklar sistemidir (Kutanis, 2010). Bu bağlamda otel yöneticileri örgüt içerisinde belirli norm ve davranışları önemsedikleri ve değer verdikleri söylenebilir. Yöneticilerin önemsedikleri son faktör ise örgütsel öğrenme faktörüdür. Yöneticilerin bu faktörü en son olarak önemsemesinin nedeni olarak diğer dört faktörün birleşiminin bir sonucu olarak ifade edilebilir. Çünkü örgütsel öğrenme, örgütün performansına katkıda bulunmak için yetenekleri ve kaynakları geliştirmeyi amaçlayan bilgiyi bütünleştirme, elde etme ve ortaya koyma sürecine zemin hazırlayan bir yaklaşımdır (Perez vd., 2005).

Çalışmanın temel kısıtı, araştırmanın sadece beş yıldızlı otel işletmelerinde yapılmış olmasıdır. Diğer bir kısıtıda araştırma verilerinin otel işletmelerinden birer üst düzey yöneticiden elde edilmiş olmasıdır. İleride bu çalışmaya benzer yapılacak çalışmalara öneri olarak;

- Çalışmada örgüt içi dinamikler, örgüt kültürü, işletme yapısının işleyiş̧i, liderlik, örgütsel öğrenme ve güç/politika olarak sınırlandırılmıştır. Bundan sonraki yapılacak çalışmalarda, örgüt içi dinamiği oluşturan farklı dinamiklere yer verilmesi,

- Bilgi yönetimi ve yenilik arasında örgüt içi dinamikler dışında var olabilecek kısmi veya tam aracı etkilerin araştırılması,

• Bilgi yönetimi, yenilik ve örgüt içi dinamikler konularını otel işletmeleri açısından daha uygulanabilir hale gelmesi için gerekli olan unsurlar araştırılabilir,

- Bilgi yönetimi, yenilikve örgüt içi dinamikler konusuna ilişkin farklı sektörlerde araştırmalar yapılabilir ve bu araştırma sonuçlarının karşılaştırılabilir,

- Otel işletmelerinde bilgi yönetimi, yenilikve örgüt içi dinamiklere ilişkin uygulamaların işletmeye kazandırdığı değerlerin ne ölçüde soyut ne ölçüde somut olduğu incelenebilir. 


\section{SON NOTLAR}

1 Makaleye "Bu makalede kullanılan verilerin bir bölümü tamamlanan doktora tezinden alınmış ve bu doktora tezi Sakarya Üniversitesi Bilimsel Araştırma
Projeleri Komisyonu tarafından desteklenmiştir (Proje no:2011-60-02-004).”

\section{KAYNAKLAR}

Avc1, U., Kılınç, İ. ve Okumuş, F. (2010) “Öğrenme Düzeyleri Arasındaki İlişki: Otel İşletmelerinde Bir Alan Araştırması" Ege Akademik Bakı̧ Dergisi, 10(1):95-115.

Aydın, Ş. (2007) "Bir Araç Olarak Örgütsel Güç Kullanımı: Sakarya Üniversitesi Araştırması" Yayınlanmamış Yüksek Lisans Tezi, Sakarya, Sakarya Üniversitesi Sosyal Bilimler Enstitüsü.

Baglieri, D. ve Consoli, R. (2009) "Collaborative Innovation in Tourism: Managing Virtual Communities" The TQM Journal, 21(4):353-364.

Bağc1, Z. (2009) "Örgütlerde Çalışanların Algıladıkları Güç Kaynaklarının Örgüte Bağlllıkları Üzerine Etkisi: Bir Araştırma" Yayınlanmamış Doktora Tezi, İzmir Dokuz Eylül Üniversitesi Sosyal Bilimler Enstitüsü.

Bayrak, S. (2001) "Yönetimde Bir İhmal Konusu Olarak Güç ve Güç Yönetimi”Süleyman Demirel Üniversitesi, İktisadi ve İdari Bilimler Fakültesi Dergisi, 6(1):23-42.

Boumarafı, B. (2009) "Knowledge Management Approachto Performance: a United Arab Emirates Experience" Digest of Middle East Studies, 18(2):17-26.

Brown, A. ve M. Patrickson (2003) "Introduction: Quality, Innovationand Knowledge" International Journal of Manpower, 24(5):499-500.

Carlsson, B. (2006) "Internationalization of Innovation Systems: A Survey of the Literature" Research Policy, 35:56-67.

Chin, K.S(2002) "Human Factorsand Ergonomics in Manufacturing” Service Industries, 12(4):365-382.

Chol, B., Poon, S.G.K ve Davis J.G. (2008) "Effects of Knowledge Management Strategy on Organizational Performance: Acomplementarity Theory-Based Approach" Omega The International of Management Journal, 36:235-251.

Cunnıngham, S. ve Higgs,P. (2009) "Measuring Creative Employment: Implications for Innovation Policy" Innovation: Management, Policy\& Practice, 11:190-200.

Çakıcı, A.C. (2006) Toplantı Yönetimi:Kongre, Konferans, Seminer ve Fuar Organizasyonları, Ankara, Detay Yayıncilık.

Çokluk, Ö., Şekercioğlu, G. ve Büyüköztürk, Ş. (2010)Sosyal Bilimler için Çok Değişkenli İstatistik SPSS ve LISREL Uygulamaları,1. Baskı, Ankara, PegemYayınları.
Demirel, Y. ve Seçkin, Z. (2008)“Bilgi Yönetimi Uygulamasında Etkili Olan Faktörler Üzerine Mobilyacılık Sektöründe Bir Araştırma” ZKÜ Sosyal Bilimler Dergisi, 4(8):107-122.

Drucker, P. (1996)Yönetim Uygulaması, İstanbul, İnkılap Kitapevi.

Du, R., S. Ai ve Ren, Y. (2007)“Relationship Between Knowledge Sharingand Performance: A survey in Xi'an China” Expert Systems with Applications, 32:38-46.

Eren, E. (2003) Yönetim ve Organizasyon Çă̆daş ve Küresel Yaklaşımlar, 6.Baskı, İstanbul, Beta Yayınları.

Frenz, M. ve Gillies, G. L. (2009)“TheImpact on Innovation Performance of Different Sources of Knowledge: Evidence From The UK Community Innovation Survey” Research Policy, 38:1125-1135.

Genç, K.Y. ve Acuner, T. (2004) "Durumsal Değişkenler Organizasyon Yapısı İlişkisinin Türkiye Çay Sektöründe Araştırılması" Osmangazi Üniversitesi 3.Ulusal Bilgi, Ekonomi ve Yönetim Kongresi Bildiriler Kitabı:729-738.

Gumusluoğlu, L. ve A. Ilsev (2009) “Transformational Leadershipand Organizational Innovation: The Roles of Internaland External Susortfor Innovation" J Prod Innov Manag, 26:264-277.

Gümüştekin, E. (2004)“Bilgi Yönetiminin Stratejik Önemi” Atatürk Üniversitesi İktisadi ve İdari Bilimler Fakültesi Dergisi, 18(3-4):201-212.

Herrmann, A., Tomczak, T. ve Rene, B. (2006) "Determinants of Radical Product Innovations" European Journal of Innovation Management, 9(1):20-43.

Hertog, P.D. ve Jong, G.D. (2007) “Randstad's Busines Model of Innovation: Results From An Exploratory Study in Temporary Stuffing Industry" Innovation: Management, Policy\& Practice, 9:351-364.

Hicks, H.G. (1975) “Örgütlerin Yönetimi: Sistemler ve Beseri Kaynaklar Açısından”Çev. Osman Tekok, Bintug Aytek ve Birol Bumin, Ankara, San Matbaası.

Huang, J.W. ve Li, Y.H. (2009) “TheMediatingEffect of Knowledge Management on Sociallnteraction and Innovation Performance" International Journal of Manpower, 30(3): 285-301. 
İnce, N. (2002) "Kamu Kurumlarında Bilgi Yönetimi: Ekonomi Alanındaki Kurumlar, Hacettepe Üniversitesi" Yayınlanmamış Doktora Tezi, Ankara Sosyal Bilimler Enstitüsü.

Jiménez, D.J. ve R.S. Valle (2010) "Innovation, Organizational Learning and Performance" Journal of Busines Research, 9:1-10.

Kanbur, A. (2008) "Küreselleşme Sürecinde Post Modern Örgüt Yapıları” Süleyman Demirel Üniversitesi İktisadi ve İdari Bilimler Fakültesi Dergisi, 13(3):387-404.

Knights, D. ve J. Roberts(1982) “The Power of Organizationor The Oganization of Power? " Organization Studies, 3(1):47- 63.

Koçel, T. (2005) İsletme Yöneticiliği, 10. Basım, İstanbul, Arıkan Yayıncılık.

Kurt, M. (2004) "İsletmelerde Bilgi Yönetimi Uygulamaları ve Rekabet Avantajina Katkıları: Siemens Busines Services (SBS) Türkiye Örneği” Yayınlanmamış Doktora Tezi, Afyon, Afyon Kocatepe Üniversitesi Sosyal Bilimler Enstitüsü.

Kutanis, R.Ö. (2002) “Öğrenen Organizasyonlar" Dalay vd.(eds),Stratejik Boyutuyla Modern Yönetim Yaklaşımları, İstanbul, Beta Basım Dağıtım.

Man, J. (2001)“Creating Innovation" Work Study, 50(6):229-233.

Mangiarotti, G. (2010) "Knowledge Management Strategiesand Innovation: An Empirical Analysis for Luxembourg"11th European Conference on Knowledge Management, September 2-3, Portugal.

Mimir, M. (2008) "Liderlik Tarzlarmın Firma Performansı ve Çalısanların Kuruma Olan Bă̆lılıklarına Etkisi Üzerine Bir Araştırma" Yayınlanmamış Yüksek Lisans Tezi, İzmit Gebze Yüksek Teknoloji Enstitüsü Sosyal Bilimler Enstitüsü.

Morales, F.X.M., Teresa, M. ve Martínez, F. (2009) "TooMuchLove in the Neighborhood Can Hurt: How An Exces of Intensity and Trust in Relationships May Produce Negative Effects on Firms" Strategy Management Journal, 30(9):1013-1023.

Nahma, A.Y., Mark, A.V. ve Koufteros, X. A. (2003) "The Impact of Organizational Structure on TimeBased Manufacturingand Plant Performance" Journal of Operations Management, 21:281-306.

Nunnally, C.J. (1957) Psychometric Theory New York, Mac Graw-Hill.

Onat, A. (2010) "Özel Hastanelerde Bilgi Yönetimi: Bir Araştırma” Yayınlanmamış Yüksek Lisans Tezi, İstanbul, İstanbul Üniversitesi Sosyal Bilimler Enstitüsü.
Özdemir, A. (2006) "Bilgi Yönetimi ve Kurumsal Yaklaşım: Çorlu İlçesi Kamu ve Özel Arşivleri İle Bilgi Merkezleri Üzerine Bir Çalışma" Yayınlanmamış Yüksek Lisans Tezi, İstanbul Marmara Üniversitesi Türkiyat Araştırmaları Enstitüsü.

Özdemir, S., Trott, P. ve Andreas, H. (2007) “New Service Development; Insights From an Explorative Study in to The Turkish Retail Banking Sector" Innovation: Management, Policy \& Practice, 9:276-291.

Plesis, M.D. (2007)“The Role of Knowledge Management inInnovation, Journal of Knowledge Management, 11(4):20-29.

Robbins, S. ve Coulter, M. (2002) Management 7th Edition, New Jersey, Prentical-Hall.

Robbins, S.P. (2000) "Esentials of Organizational Behavior” New Jersey, Prentice Hall.

Selimoğlu, N. (2005) "Sürę̧ Yönetimi ve Sürȩ̧ Iyileştirmede Bilgi Yönetiminin Rolü ve Uygulamaya İlişkin Bir Araştırma" Yayınlanmamış Yüksek Lisans Tezi, İstanbul, İstanbul Üniversitesi, Sosyal Bilimler Enstitüsü.

Soylu, A. ve Meltem, Ö.G. (2010) "Yönetim İnovasyonu" Sosyoekonomi, 1:113-130.

Sönmez, A. (2007) “Örgütlerde Çalışanları Güçlendirmeye Yönelik Uygulamalarn Rekabet Gücüne Etkisi: Bucak/Burdur Bölgesi 3s Plazalar Örneği” Yayınlanmamış Yüksek Lisans Tezi, Kütahya, Dumlupınar Üniversitesi Sosyal Bilimler Enstitüsü.

Tajeddini, K. (2009) "Perceptions of Learning Among Swis Watch Managers" Journal of Workplace Learning, 21(7):525-537.

Tutar, F., Kocabay, M. ve Arıç, H. (2007) "Firmaların Yenilik (İnovasyon) Yaratma Sürecinde Serbest Bölgelerin Rolü: Kayseri Serbest Bölgesi Örneği” Selçuk Üniversitesi Karaman İktisadi ve İdari Bilimler Fakültesi Dergisi, Yerel Ekonomiler Özel Sayısı, 195-203.

Ulusoy, G., Lütfihak, A., Kemal, K. ve Atilla, Ö. (2008) "Imalat Sanayinde Inovasyon Modelleri ve Uygulamaları Projesi" Tübitak, Proje No: SOBAG $-105 \mathrm{~K} 105$.

Uzkurt, C. (2010)“İnovasyon Yönetimi: İnovasyon Nedir, Nasıl Yapılır ve Nasıl Pazarlanır?” Ankara Sanayi Odası Yayın Organı, 37-51.

Uzun, D. (2007) “Örgüt Kültürünün Bilgi Yönetim Sürecine ve Örgütsel Performansa Etkisi: Beş Yildızlı Otel İsletmelerinde Bir Uygulama" Yayınlanmamış Doktora Tezi, İzmir, Dokuz Eylül Üniversitesi Sosyal Bilimler Enstitüsü. 
Xu, J.,Houssin, Emmanuel, C.R. ve Gordoni, M. (2010)"Macro Process of Knowledge Management forContinuousInnovation" Journal of Knowledge Management, 14(4):573-591.

Yıldırmaz, H. (2006) "Bilgi, Bilgi Yönetimi ve Sürdürebilir Rekabet Avantajı, Yeditepe Üniversitesi” Yönetim Uygulama ve Araştırma Merkezi, Araştırma Notu.

Yılmaz, V. ve Çelik, E. H. (2009)Lisrel ile Yapısal Eşitlik Modellemesi I, Ankara, Pegem Yayınları.

Yılmaz, Y. (2007) "Işletmelerde Kurumsallaşmanın Yenilik ve Performansa Etkisi" Yayınlanmamış Yüksek Lisans Tezi, İzmit, Gebze Yüksek Teknoloji Enstitüsü Sosyal Bilimler Enstitüsü.
Zhang, J.C., Anthony, D.B. ve Hoenig, S. (2009)"Product Development Strategy, Product Innovation Performance, and the Mediating Role of Knowledge Utilization: Evidencefrom Subsidiaries in China" Journal of International Marketing, 17(2):42-58.

Zona, M.G. (2009) "Innovation-as-practice: Examining the relationship between leaders' espousedandenacted Innovationand Innovation Outcomesand Firm Performance" Unpublished Disertations \& Theses, London, The University of Western Ontario Richard Ivery School of Busines. 